\title{
Examining the Existence of "Teaching to the Test" at SSC Level in Bangladesh
}

\author{
Forhad Jamila1, Mohammed Humayun Kabir ${ }^{2}$ \\ ${ }^{1}$ Department of Humanities, Chittagong University of Engineering and Technology, Raozan Upazila, Bangladesh \\ ${ }^{2}$ Department of English Language and Literature, International Islamic University Chittagong, Chittagong, Bangladesh \\ Email: humayun002003@yahoo.com
}

How to cite this paper: Jamila, F., \& Kabir, M. H. (2020). Examining the Existence of "Teaching to the Test" at SSC Level in Bangladesh. Creative Education, 11, 558-572. https://doi.org/10.4236/ce.2020.114041

Received: March 21, 2020

Accepted: April 17, 2020

Published: April 20, 2020

Copyright (c) 2020 by author(s) and Scientific Research Publishing Inc. This work is licensed under the Creative Commons Attribution International License (CC BY 4.0).

http://creativecommons.org/licenses/by/4.0/

\begin{abstract}
The paper aims at examining the influence of Secondary School Certificate (SSC) English language test on teaching in the existing CLT-based teaching context in Bangladesh. It is a fact that SSC test results continue to influence the total educational career of a student including his admission into Higher Secondary Certificate (HSC) level and subsequently at tertiary level study. Later on, SSC result is one of the vital determinants of his employment. As a result, the washback effect i.e. effect of test (SSC EFL tests) on teaching and learning of this high stakes test cannot be ruled out. The overwhelming use of test results in different academic and professional affairs in the context of Bangladesh has made the effect of washback a distinctive educational phenomenon. This study presents preliminary research findings on the SSC EFL test's influence on teaching in Bangladesh by applying various methodological techniques such as classroom observation and teacher interview in sampled schools located in Chittagong, Bangladesh. The analysed data revealed that SSC EFL test technique is one of the driving forces that shape teaching. Teachers' teaching is confined to only those tasks and activities which are commonly set in the tests. Now it is difficult to deny that that teaching to the test is a harsh reality at SSC level classrooms in Bangladesh.
\end{abstract}

\section{Keywords}

Washback, Teaching to the Test, National Curriculum (NC) 2012, SSC

English Test, CLT \& GTM

\section{Introduction}

In the existing educational framework of Bangladesh, Secondary School Certificate (SSC) is a "O" level equivalent education program or test that students take upon the completion of ten years of studies (from Grade I to Grade X). English 
is a compulsory subject which is taught from Grade I to Grade XII in the educational arrangement of Bangladesh. The history of formal education system in Bangladesh reveals that Grammar Translation Method (GTM) is the oldest English language teaching method in the formal education system in this context. However, we find that in late 1990s, language teaching paradigm shifted from Grammar Translation Method (GTM) to Communicative Language Teaching (CLT). "This change in pedagogy and approach, replacing the traditional grammar-translation method, was necessary to help learners communicate in English meaningfully and spontaneously. Considering this learning need, the country adopted Communicative Language Teaching (CLT) from primary to higher secondary level was introduced in 1996" (National Curriculum, 2012: p. 73).

The purpose of introducing CLT is to make English language teaching and learning more effective as the demand of proficiency in English language is ever growing not only in Bangladesh but also beyond the territory of the country. It is almost two decades passed since the introduction of CLT in this country. Now it is the time to assess the success of CLT in teaching English. The quality of English language teaching and testing at Primary, Secondary and Higher Secondary levels is questioned by a host of researchers (Kabir, 2015a, 2015b; Billah, 2015; Mariyam et al.; 2015; Alam \& Kabir, 2015). We assume that CLT approach was introduced considering its effectiveness in language teaching. New textbooks were published and CLT based tests were introduced and it was expected that post CLT era of English language teaching and learning outcome would be better one. Host of studies (Hamid \& Baldauf, 2008; Kabir, 2008; Kabir, 2009) show that CLT is not as effective as it was thought of in the context of Bangladesh.

Numerous studies (see, Ali, Hamid, \& Hardy, 2018; Rahman, Sing, \& Pandian, 2018; Ali \& Walker, 2014; Begum \& Farooqui, 2008; Kabir, 2007) have identified that English language tests at schools in Bangladesh are conventional and the assessment procedure is flawed one. Besides, even though there is a shift of language teaching paradigm in Bangladesh (from Grammar Translation Method to Communicative Language Teaching), a corresponding change has not been found in English as Foreign Language (EFL) test pattern; as a consequence, teacher cum test designers are still noticed to adopt the same teaching technique and to test same type of test items which maintain a strong legacy with Grammar-Translation Method (see Billah, 2015; Ali \& Walker, 2014; Hamid \& Baldauf, 2008; Haider \& Chowdhury, 2012). It is also feared that SSC curriculum innovation might be adversely affected if the present testing policy does not endorse the principles of the curriculum.

Despite the fact that officially CLT is in action, it is found that students tend to memorize answers to the probable questions that are likely to appear in SSC which indicates that students and teachers can predict SSC test items. This character of SSC English test emboldens the learners to restrict their range of study and influence the teachers to teach only those probable items. This tendency of restricting teaching and learning is known as harmful washback in English Language Teaching. 


\subsection{Education System of Bangladesh}

In order to give an idea of the schooling system of Bangladesh, the researcher introduces the education system of Bangladesh in brief in this section.

Middlehurst \& Woodfield (2004: p. 4) state that "the education system of Bangladesh consists of three principal stages: primary, secondary, and higher/tertiary education. In parallel to mainstream formal education, students can also choose to study at Madrashas that offer Islamic religious education. There are government supported and private educational institutions at all educational levels".

This study deals with Secondary School Certificate (SSC) English teaching and testing. For this reason a brief discussion is made on SSC English test which consists of two papers i.e. English $1^{\text {st }}$ and English $2^{\text {nd }}$ paper.

\subsection{Structures of SSC English Test}

SSC level students have to sit for two English language tests known as English First Paper and English Second Paper. Each of the papers carries 100 marks.

English First Paper mainly tests Reading and Writing skills. 50\% marks are allocated for each of the skill. Marks distribution system of SSC English tests is presented below:

Reading items tested: MCQ, Answering questions (open \& close ended, Gap filling without clues), Information transfer, Summarizing, Matching, Rearranging.

Writing items tested: Writing paragraph answering questions, Completing a story, Writing informal letter/email, Describing graphs/ charts and Writing dialogues.

English Second Paper tests grammar and composition: For Grammar items $60 \%$ marks are allocated.

Grammar Items tested: Gap filling activities with clues (Preposition, Articles, Parts of speech), Substitution table, Right form of verbs, Narrative styles (direct to indirect and/or vice versa), Changing sentences (change of voice, sentence patterns and degrees), Completing sentences (using conditionals, infinitive, gerund, participle), Using suffix and prefix, Tag questions, Sentence connectors, Punctuations.

In the writing part $40 \%$ marks are allocated for Composition.

Composition includes: Writing CV with cover letter, Formal letters/email (complaint letter, notice, purchase order, Response to an order/request etc., Paragraph writing by listing/narrating/comparison and contrast/cause and effect and Writing composition on personal experience and familiar topics, recent events/incidents, future plans.

\subsection{The Rationale of the Study}

The National Curriculum 2012 focuses on "teaching-learning English as a skill-based subject" (p. 73). This updated curriculum seeks to develop English language proficiency in the learners through language activities related to prac- 
tical and real life situations. Teachers are suggested to prepare more teaching-learning activities (authentic texts and tasks) following the model language tasks and activities provided in the textbooks and Teacher's Curriculum Guide (TCG). The curriculum suggested that four language skills of speaking, listening, reading and writing have to taught and tested. However, SSC English examinations cover mainly- grammar, reading and writing, while the other two skills of listening and speaking are not formally assessed. So a study is necessary to examine the existence of teaching to the test at SSC level.

\subsection{Significance of the Study}

CLT is the officially adopted English teaching approach in Bangladesh. That is why it is expected that teachers would teach four major language skills as it is suggested by the curriculum. They are also advised to use authentic materials in the class besides, the official textbooks. The ground realities are different now. It is often reported that edu-business (shadow education) is thriving in Bangladesh. Commercialisation of education has reached an alarming level as test directed teaching dominates. In this study we examined whether teachers' are engaged in teaching to the test items which are tested in SSC. It is really a crucial issue because it might identify the reasons why teaching to the test exists in a context where CLT is officially functional. The findings will help the authority to take measure to contain this harmful practice. We assume people related to education administration will benefit from this study.

\subsection{Statement of the Problem}

Numerous studies uncovered that SSC English test lacks validity and reliability and it is a predictable test (Kabir, 2007; Kabir, 2008; Kabir, 2009). Mismatch is evident between curricular goals and classroom activities. All of these features are having detrimental effect on SSC English test. It is reported that teachers teach some selective tasks and activities though there are two well designed English textbooks published by National Curriculum and Textbook Board (NCTB).Some researchers hold that teachers do it because of the nature of the test. This study aims at revealing why and how classroom teaching is guided and/or influenced by the SSC test.

\subsection{Research Questions}

In this present study we designed the following researcher questions with a view to finding the answer to the problems that we have stated in the above section.

1) What are the contents of SSC EFL test?

2) What sort of teaching materials are used in classroom teaching at SSC level?

3) To what extent does the SSC English test influence classroom teaching?

\section{Review of the Literature}

In this part of review of the literature we discussed use of Test in the Education 
System of Bangladesh, Present SSC English Curriculum, the objectives of the SSC English curriculum, wsahback and teaching to test.

\subsection{Present SSC English Curriculum}

Bangladesh adopted CLT replacing Grammar Translation Method (GTM) in late 1995 in order to develop communicative competence among the Bangladeshi learners so that they can adjust themselves in this globalised world. Considering the learning needs the focus is given on developing communication skills rather than developing grammar skill. The National Curriculum 2012 clearly focuses on teaching-learning English as a skill-based subject which will enable our learners to use English in their real life situations. The newly implemented curriculum shifts its focus on teaching all four major language skills instead of teaching grammar, reading and writing skills.

National Curriculum 2012 instructs that:

- All the four basic language skills would be practised in class.

- Skills should be practised in an integrated manner-not in isolation.

- Skills practice should be done in meaningful context, i.e. practice in language use should go beyond the text book and include real-life situations.

- Interactive activities should be carried out between teachers and students, and more importantly between students and students...

There will also be provisions for using supplementary reading materials to develop learners' reading skills. Grammatical elements will be integrated into the text materials. With a view to reinforcing learners' accurate use of language, communicative English grammar will be taught simultaneously (National Curriculum, 2012: p. 73).

\subsection{Use of Test in the Education System of Bangladesh}

It is true that test plays a vital role in any academic setting and Bangladesh is not an exception. However, the major concern of the parents, teachers and learners is to manage a good grade in English in the test. The whole nation concentrates on test results when it is published. The researchers share the same view with Billah (2015: p. 12) who maintains that "All the stakeholders of learning English primary, secondary, higher secondary or even tertiary levels concern only for crossing the stairs of pass through easier and quicker way".

Bangladeshi examination system as well as teaching at SSC and HSC levels hardly develops students' ability to use English in practical life. Observing the scenario of Bangladesh, Billah (2015: p. 13) states that "The English they learn in the classroom helps them just to prepare and manage marks in the typical examination". So tackling the hurdle of test is the main goal of the people of all spheres of Bangladesh.

It is teacher who prepares/teaches/supervises a student for any sort of academic test because a student faces a test upon completion a particular course to ascertain whether the goals and objectives of the course are achieved. In any 
academic setting teachers are usually found to guide their students so that they may do well in the upcoming test. We do not find any wrong when it is noticed that students are receiving some techniques from their teachers to achieve better grades. However, if tests decide what to teach and how to teach it is harmful. The influence of tests on teaching and learning is called washback.

\subsection{Wsahback and Teaching to Test}

Experts in testing opine that the effect of a test on a teacher's teaching and a learner's learning is known as washback or backwash (Hughes, 2003). It is very sensible and reasonable to consider that a test exerts significant level of influence upon the teachers and this influence is substantial especially when it is a high stakes test. Johnson (1989: p. 6) maintained that "in many education systems the key questions for students, teachers, parents, school administrators, and even inspectors is not, 'Are students gaining in communicative competence?' but, 'Are they on course for the examination?'”

Generally, students depend on their teachers for any sort of help regarding test preparation. That is why "teachers have been the most frequent case of studies on washback", Birjandi \& Taqizadh (2015: p. 9). Bailey (1999: p. 17) maintains that "the most visible participants in washback program are teachers. It is they who are the 'front-line' conduits for the washback processes related to instruction."

In this commercial world teachers cannot always stick to their principles. Sometimes they are compelled to compromise the principle of teaching. Good results of the students of an institution make its image and on the other hand bad results seriously damage its reputation which ultimately affects student enrollment in days to come. So teachers are very much concerned about any high stakes test like SSC in Bangladesh. That is why it is understood that tests influence teaching and it is likely to influence the behavior of the students, provided that they become "test wise". Like Pizarro (2010), Xie \& Andrew (2013), Birjandi \& Taqizadh (2015: p. 9) too agree with Hughes (1993) when they point out that "when a test or a new syllabus or a new textbook is introduced, teachers try to prepare their students for the tasks which would be expected of the students at the end of the course". Indeed, the power of test cannot be ignored.

The researchers in this study are desirous to examine whether teachers tend to teach the test as a result of the washback effect of SSC English test.

\section{Methodology}

The current study utilised a qualitative research approach to answer the research questions developed for the study. We have used two methods namely observation and interview analysis. For the sake of greater validity and reliability of this research, we used classroom teaching observation and teacher interview to investigate the ways how (SSC) test influences teaching. Cheng, 2005; Wall, 2005 and Yi-Ching Pan 2013 suggest that it is crucial to combine asking which in- 
cludes interviews and questionnaires, and watching i.e. observation to explore the nature of washback effects. By employing two methods (interview and observation), current study tried to ascertain the effects that test has upon teaching practices.

\subsection{Context}

The study took place in Chittagong city, one of major cities of Bangladesh under Chittagong Education Board. We have selected two (2) government secondary schools out of eight and two (2) private secondary schools out of over hundred secondary schools randomly for collecting data. Here it has to be mentioned that government schools are completely funded and teachers working there are recruited by the government whereas private schools are partially or not at all funded by the government and the concerned school authority recruit required number of teachers who are novice teachers without any professional training. The nongovernment schools are the absolute majority in terms of number. However, both types of schools have to comply with government directions. It has to be noted that there are eight education boards in Bangladesh to regulate the entire education administration at secondary and higher secondary levels. We included both type of schools in order to recognize disparity, if any, between the institutions. Equal number of teachers was also selected from both type of schools to make a balance.

\subsection{Participants}

In this study the interview was conducted with 8 English teachers from 4 secondary schools. All teacher-participants are engaged in teaching English with the experience of a minimum of 12 years to a maximum of 30 years. The English teachers were selected purposefully so that they could respond to the questions related to English reaching/learning and testing pattern at SSC level. The teacher-participants belonged to both government and private schools. We carried out 12 observation sessions in those four secondary (high) schools. As there are provisions for coeducation system and separate schools for boys' and girls', this study included both types of schools with a view to ensuring valid, reliable and trustworthy data.

\subsection{Instrumentation and Data Collection}

Current study considered two data collection instruments (interview and observation protocols) to complement each other. Before the final data was collected, the instruments were piloted in two private schools in the western part of Chittagong city which helped us to remove some of the confusing items and at last we could finalize the instruments.

\subsubsection{Interview}

Teachers were interviewed in order to ascertain what sort of influence SSC English tests have on classroom teaching. Interview allows the researcher to produce 
detailed data, based on informants' priorities, opinions and ideas, Chowdhury (2008). It is used as the main tool of data gathering for most studies employing qualitative approach as done by Saad (2014), Hamid (2009), Chowdhury, 2008. Researchers usually conduct either semi-structured or in-depth interviews. This gives a holistic understanding which is the main advantage of interview.

In this study, interview was used as a means of data collection to gather more direct information from the practicing English teachers. It is a fact that interviews create an opportunity "to gather data that would offer deeper insights than questionnaires could provide, even if it meant working with fewer participants" Wall and Horak (2006: p. 26). A semi-structured interview schedule was used in this regard. In the interview we focused mainly those areas which were observed in the classroom teaching observation.

\subsubsection{Observation}

In order to see what really happens inside the classrooms an observation schedule was used to collect data for this study. It helped the researchers to observe the real scenario of the classrooms. We could match the interview responses and actual classroom activities by the help of observation. The main focus of the observation included the following issues:

1) Teaching methods and materials used in the classrooms.

2) Skills covered in the class.

3) SSC test's influence on classroom teaching.

A checklist (see Appendix-4) was prepared and used during observation so that no significant issue related to the study might be missed. Altogether 12 classes were observed. Before observing the class, necessary permission was taken from the Head Master as well as from the class-teacher.

Observation of classroom teaching activities was a data gathering method which was used to see whether SSC test shaped teaching activities in the classroom teaching. This method refers to the situation seen through the other person's eyes and perspectives. Saad (2014: p. 78) holds that "It is axiomatic that there are a lot of strategies which happen in the mind like cognitive, metacognitive and also affective strategies. Thus, this tool is not a stand-alone tool; it can be employed to support other tools". Pan (2008: p. 7) maintains that "if we wish to know whether an exam can bring about changes in classroom teaching and learning, we must first examine the classroom itself, since that is where most teacher-student interaction occurs". So the importance of observation can easily be perceived. Through observation it is easy to detect the gap between theory and practice if it exists there.

\section{Data Analysis and Findings}

It is already mentioned that we used teacher interview and classroom observation to bring forth whether teaching to test exists in SSC classrooms. Below, there will be discussion on the collected data through classroom observation and teacher interview. 


\subsection{Analysis of Classroom Observation}

We already mentioned that 4 secondary schools were selected and 12 teachers' classes (six (6) English $1^{\text {st }}$ Paper and six (6) English 2nd Paper) were observed. It was found that teachers mostly taught reading, writing and grammar skills. Listening and speaking skills were ignored in the classroom activities. Teachers as well as students follow some commercially published guide/note books in the classroom. Task and activities were practiced from there instead of NCTB (National Curriculum and Textbook Board) prescribed texts. Furthermore, we noticed that only those tasks are discussed which are generally tested in SSC exam. The following table included a summary of the content which we observed (6 classes out of twelve) (Table 1).

Table 1. Summary of the observed classes.

\begin{tabular}{|c|c|c|c|c|c|}
\hline Observation Sessions \& Date & Skill covered & Topic taught & $\begin{array}{c}\text { Teaching material } \\
\text { Used }\end{array}$ & $\begin{array}{l}\text { Test's influence on } \\
\text { teaching noticed? }\end{array}$ & $\begin{array}{l}\text { Length } \\
\text { of class }\end{array}$ \\
\hline Session i 25-07-2019 & Writing skill & Dialogue writing & Guidebook & Yes & 45 minutes \\
\hline Session-iii 25-07-2019 & Reading skill & $\begin{array}{l}\text { Reading passage: } \\
\text { National Memorial }\end{array}$ & NCTB textbook & Yes & 45 minutes \\
\hline Session iv 26-07-2019 & Grammar skill & Reported speech & Guidebook & Yes & 45 minutes \\
\hline Session vi 28-07-2019 & Grammar skill & Transformation of sentences & Guidebook & Yes & 45 minutes \\
\hline Session vii 30-07-2019 & Writing skill & Job application writing with $\mathrm{CV}$ & Guidebook & Yes & 45 minutes \\
\hline Session viii 30-07-2019 & Reading skill & $\begin{array}{c}\text { Reading passage: } \\
\text { Pohela Baishak } \\
\text { (Bangla New year) }\end{array}$ & NCTB textbook & Yes & 45 minutes \\
\hline
\end{tabular}

The table above shows what the observation sessions explored. During observation no teacher was found to teach Listening and/or speaking skills and Reading skill received teacher's attention. However, they were found to use the guide/note books instead of any authentic materials. It was also observed that Writing skill was practised from different commercially published guide books. Grammar skill was taught in isolation and item by item. Students were found to be simply silent recipients in the class.

Under the above given context, it is understood that SSC EFL tests include Reading and Writing skills and exclude Listening and Speaking skills and as a consequence Listening and Speaking skills were not included in the class lecture. Teachers' interview also affirmed it.

\subsection{Findings Form Observation}

We observed that SSC exam had strong influence upon classroom teaching. None of the teachers were found to teach speaking and listening skills. Obviously, it is a sheer violation of SSC curriculum guideline. It is presumed that teachers are reluctant to teach these two skills because these are not tested in SSC. It 
was surprising that even the school syllabus asked the students to procure commercially published Grammar and composition books. No teacher or student brought NCTB published textbook in the classroom. Guide books were used to teach grammar or practice language tasks. All of these activities indicated that teaching to the test prevails in SSC level teaching and learning.

\subsection{Analysis of Teacher Interview}

When teachers' opinions were sought regarding the teaching contents, teachers opined in the following manner:

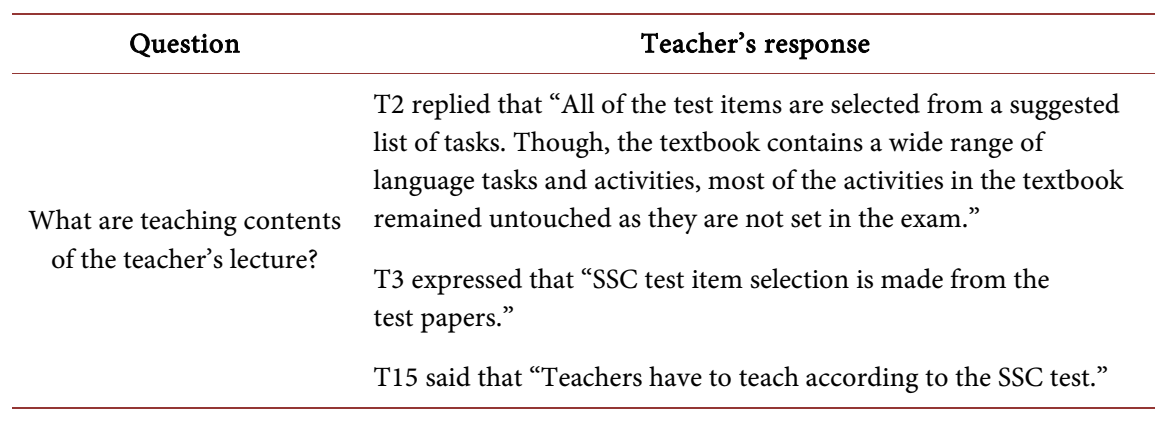

From the teachers' responses noted above it was revealed that SSC test related items are regularly taught in the class. One of the teachers informed that English textbooks contained varieties of language tasks which are really supportive to promote language proficiency of the students. However, most of those language tasks and activities are not practised as SSC test did not include those.

We also wanted to know the reason why only some selected tasks are taught and practiced in the class. The following chart consists the responses of the teachers.

\begin{tabular}{cl}
\hline \multicolumn{1}{c}{ Question } & \multicolumn{1}{c}{ Teacher's response } \\
\hline $\begin{array}{c}\text { T5 replied "We need to ensure good results, so only important } \\
\text { items have to be taught". } \\
\text { given in text are not taught } \\
\text { in the class? }\end{array}$ & $\begin{array}{l}\text { T7 said “Our school authority, including Headmaster, wants } \\
\text { that students should be well prepared for the test". }\end{array}$ \\
$\begin{array}{l}\text { tag questions, transformation of sentences, reading passages, } \\
\text { paragraph/essay writing, letter, email, CV and job application } \\
\text { regularly in the class because students will find question from } \\
\text { these area. We have to prepare them well for the SSC exam." }\end{array}$ \\
\hline
\end{tabular}

Teachers' responses noted above explored what they taught and why they taught some particular items. One of the participants clarified that they are under pressure to teach some specific items which are tested at SSC. They work under some compulsion. They need to comply with the school administration. As at the end of the day good results matter, teachers remain occupied with test directed teaching activities. 
We asked practicing teachers whether teaching to the test exists. Teachers acknowledged that teaching to the test exists at the secondary level. The following chart recorded teacher's responses.

\begin{tabular}{cc}
\hline Question & \multicolumn{1}{c}{ Teacher's response } \\
\hline $\begin{array}{l}\text { "Is there any existence of } \\
\text { teaching to the test at SSC } \\
\text { classrooms? If 'yes' why?" }\end{array}$ & T2 opined that "Yes. In Bangladeshi context it is useful". \\
& $\begin{array}{l}\text { T6 replied, "Yes. It is greatly beneficial and it prepares } \\
\text { students for the test". }\end{array}$ \\
\hline
\end{tabular}

It was explored that test guides teaching at SSC classroom. One of teachers observed that teaching some selected items is very beneficial as it prepares students for the impending test. Teachers opined that rigorous practice helps students to perform better in the tests. This participant agreed that teaching is guided by test. So, it is evident that exam-oriented teaching prevails because test items can be predicted.

We also asked the teachers whether they rely on past test papers/sample (model) questions to prepare students for the final examination. From the responses we learnt that practising past test papers and model questions is the most common practice of the country and culture of the schools. T1 said "Students might be in inconvenient position in the final test and then teachers would be considered responsible for poor results. Years after years it is found extremely helpful".

T7 stated "Students, guardians, senior colleagues and head-teacher/principal insist on revising the important tasks and activities only so that they (student) can make better results".

It is very interesting to see that only one respondent (T3) said that he does not depend on commercial materials rather he produces his self designed model questions to prepare students for SSC exam.

Teachers were also asked whether Speaking and Listening skills are regularly taught. In response 100\% participants replied that these skills are not tested in SSC. So they find it is fruitless to spend time to teach those skills in the class.

\subsection{Findings from Interview}

From the responses it is understood that, teachers believed that if the commonly tested items are taught seriously, students would be able to perform well in the test and at the end a good result can be expected. It is further learnt that school administration also desire that teachers should teach the probable items with maximum seriousness in order to prepare the students for the test. On top of that, learners also wanted that probable items should be taught in the class. So it was pointed out that students also did not like to practise those language activities which are not set in the test. It seems that teachers and students can guess the test items which will probably be set in the exam. That is the reason why, all 
focused on those items only. As a consequence, teaching to the test prevails.

The participants agreed that test directed teaching is common in SSC classroom. As the SSC is a high stakes test, it receives a lot of attention from all stakeholders. There is a widespread worry among all to make good result because it will decide students' future academic or professional career. So test results matter a lot. It is evident that teaching to the test exists at the SSC level. Teachers and students spend a big percentage of their time in test preparation. It appears that obtaining impressive results is a matter of great concern of all.

Though officially it is claimed that CLT principles are followed at SSC, in reality, the scenario is reversed. Due to the predictable nature of the test, teachers and students can anticipate the test items in advance. Furthermore, the impact of SSC test results on students' future career seemed to affect teaching tremendously. Moreover, pressures from the institution, society and administration for better result directly influenced teachers to align their teaching methodology with the tests. In effect, teaching to the test is a regular occurrence at the secondary schools of Bangladesh.

\subsection{Summary of the Findings}

The analysis of observation data and interview data revealed a well synchronized finding which indicated that SSC test controls classroom teaching activities. The above data analysis explored that SSC English test is a predictable test which emboldened teachers to teach some selected items and in effect, the teaching and learning activities are very much test directed. It is further observed that the whole nation is obsessed with making good results instead of promoting/developing communication skills. The learners contained their study within some probable tasks and teachers also seriously restricted their range of teaching activities. As a consequence harmful washback exists. It was also revealed that students and teachers used some commercially published materials which is known as guidebooks/notebooks in Bangladesh. All of these features suggested that teaching to test is a commonly noticeable phenomenon in the educational landscape at the secondary level in Bangladesh.

\subsection{Recommendations}

After analyzing the findings of the study, we like to suggest the following measures to check teaching to test at SSC level in Bangladesh:

1) SSC test should be designed in line with the Goals and objectives of SSC English curriculum

2) All four major language skills have to be taught and tested despite there are some contextual limitations.

3) Classroom teaching has to be monitored regularly by the education administrators to ensure that CLT principles are implemented.

\section{Conclusion}

SSC is a milestone in the academic career of the students of Bangladesh. It is the 
most widely known and internationally recognized test prior to HSC. The flawed SSC testing system has taken control over the classroom activities by its immense but harmful influence on teachers and students. Teachers continue to behave like the slaves of this test, because test results are the most important issue in the context of Bangladesh. We presume that our education system has entered into a vicious cycle. This small scale research revealed that due to some irresistible external pressure, teachers are engaged in teaching the test at SSC level and it is a clear indication of the derailment of the existing curriculum. The success of the introduction of CLT is questioned due to the harmful backwash effect of SSC test. SSC testing system tends to narrow down the curriculum as teachers put attention to those tasks and activities that are most relevant to the test. Unless this is reversed, teachers will continue to teach the test willingly or unwillingly. We also agree that "as all four language skills are included in the curriculum, it is justifiable to include speaking and listening as well in the assessment framework" (Das et al., 2014: p. 339) because CLT approach is recommended by the functional curriculum. Furthermore, support from stakeholders is required to make the curriculum effective with a view to developing communication skills.

\section{Conflicts of Interest}

The authors declare no conflicts of interest regarding the publication of this paper.

\section{References}

Alam, M. S., \& Kabir, M. H. (2015). Assessing the Gap between Theory and Practice in Implementing CLT at Secondary Level in Bangladesh: A Case Study. Research on $\mathrm{Hu}$ manities and Social Sciences, 5, No. 1. http://www.iiste.org

Ali, M. M., Hamid, M. O., \& Hardy, I. (2018). Ritualisation of Testing: Problematising High-Stakes English-Language Testing in Bangladesh. Compare: A Journal of Comparative and International Education, 1-21. https://doi.org/10.1080/03057925.2018.1535890

Ali, M., \& Walker, A. L. (2014). Bogged Down ELT in Bangladesh: Problems and Policy: Investigating Some Problems that Encumber ELT in an EFL Context. English Today, 30, 33-38. https://doi.org/10.1017/S0266078414000108

Bailey, K. M. (1999). Wasback in Language Testing: TOEFL Monographs Series MS-15. Princeton, NJ: Educational Testing Service.

Begum, M., \& Farooqui, S. (2008). School Based Assessment: Will It Really Change the Education Scenario in Bangladesh? International Education Studies, 1, 45-53. https://doi.org/10.5539/ies.v1n2p45

Billah, M. (2015). Language and Education Inside and Beyond the Classroom, Murdhonno, Dhaka, Bangladesh.

Birjandi, P., \& Taqizadh, M. (2015). What Drives High School English Teachers to Teach the Way They Do? An Investigation of the Washback Effect of the University Entrance Examination in Iran.

Cheng, L. (2005). Changing Language Teaching Through Language Testing: A Washback 
Study. Cambridge: Cambridge University Press.

Chowdhury, M. R. (2008). Globalisation, International Education and the Marketing of TESOL: Student Identity as a Site of Conflicting Forces. Unpublished $\mathrm{PhD}$ Thesis, Monash: Monash University.

Das, S. et al. (2014). Policy versus Ground Reality: Secondary English Language Assessment System in Bangladesh. Curriculum Journal, 25, 326-343. https://doi.org/10.1080/09585176.2014.909323

Haider, M. Z., \& Chowdhury, T. A. (2012). Repositioning of CLT from Curriculum to Classroom: A Review of the English Language Instructions at Bangladeshi Secondary Schools. International Journal of English Linguistics, 2, 12-22. https://doi.org/10.5539/ijel.v2n4p12

Hamid, M. O. (2009). Sociology of Language Learning: Social Biographies and School English Achievement in Rural Bangladesh. Queensland: University of Queensland.

Hamid, M. O., \& Baldauf, R. (2008). Will CLT Bail out the Bogged Down ELT in Bangladesh? English Today, 24, 16-24. https://doi.org/10.1017/S0266078408000254

Hughes, A. (1993). Backwash and TOEFL 2000. Unpublished Manuscript, Reading, England: University of Reading.

Hughes, A. (2003). Testing for Language Teachers. Cambridge: Cambridge University Press.

Johnson, P. (1989). Contrastive Evaluation and the Improvement of Teaching and Learning. Teachers College Record, 90, 509-528

Kabir, M. H. (2007). An Investigation into the Validity and Reliability in Testing Reading and Writing Skills at Higher Secondary Certificate Level in Bangladesh. Essex: University of Essex, UK (Unpublished).

Kabir, M. H. (2008). How Validity Is Ensured in Our Language Test: A Case Study. IIUC Studies, 5, 37-52.

Kabir, M. H. (2009). How Much Reliable are Our Language Tests? A Case Study. Crossings: ULAB Journal of English Studies, 2, No. 1.

Kabir, M. H. (2015a). Effect of Bangladeshi English Language Testing on Teaching and Learning: A Case Study. The International Institute for Science, Technology and Education (IISTE).

Kabir, M. H. (2015b). NCTB English Curriculum and Implementation of Textbook at Primary Level in Bangladesh: An Assessment. Global Journal of Human Social Science Research, 15, No. 12. http://www.GlobalJournals.org

Mariyam, T., Kabir, M. H., \& Ullah, M. M. (2015). Casting the Authority or Holding It Still: An Investigation of Teachers' Role in CLT Classrooms in Bangladesh. The International Journal of Social Science, 37. http://www.Tijoss.com

Middlehurst, R., \& Woodfield, S. (2004). Transitional Report-Case Study Bangladesh (October 2003). Commonwealth of Learning and UNESCO.

National Curriculum (2012). National Curriculum \& Textbook Board.

Pan, Y. C. (2008). A Critical Review of Five Language Washback Studies from 1995-2007: Methodological Considerations. JALT Testing \& Evaluation SIG Newsletter, 12, 2-16.

Pan, Y. C. (2013). Does Teaching to the Test Exist? A Case Study of Teacher Washback in Taiwan. The Journal of Asia TEFL, 10, 185-213.

Pizarro, M. A. (2010). Exploring the Washback Effects of a High-Stakes English Test on the Teaching of English in Spanish Upper Secondary Schools. Revista Alicantina de Estudios Ingleses, 23, 149-170. https://doi.org/10.14198/raei.2010.23.09 
Rahman, M. M., Singh, M. K. M., \& Pandian, A. (2018). Exploring ESL Teacher Beliefs and Classroom Practices of CLT: A Case Study. International Journal of Instruction, 11, 295-310. https://doi.org/10.12973/iji.2018.11121a

Saad, N. S. B. M. (2014). The English Language Learning Experiences of International Students. PhD Thesis (Unpublished), Malaysia: Universiti Kebangsaan Malaysia.

Wall, D. (2005). The Impact of High-Stakes Examination on Classroom Teaching. Cambridge: Cambridge University Press.

Wall, D., \& Horak, T. (2006). The Impact of Changes in the TOEFL Examination on Teaching and Learning in Central and Eastern Europe: Phase I, The Baseline Study. https://doi.org/10.1002/j.2333-8504.2006.tb02024.x

Xie, Q., \& Andrew, S. (2013). Do Test Design and Uses Influence Preparation? Testing a Model of Washback with Structural Equation Modeling. Language Testing, 30, 49-70. https://doi.org/10.1177/0265532212442634 